\title{
WOMEN IN ISLAMIC EDUCATION MANAGEMENT: Learning From Pesantren Practices
}

\section{Siti Nur Hidayah and Ahmad Arifi}

Faculty of Tarbiyah and Teaching

State Islamic University (UIN) Sunan Kalijaga Yogyakarta

Email: enh_hidayah@yahoo.com; shidayah.ugm@gmail.com

\begin{abstract}
This paper focuses on two issues. Firstly, the role performed by women (nyais) in managing pesantren by considering the issue of work division, authority and responsibility principles in management practices. Secondly, it observes on how knowledge is managed and preserved in pesantren. This paper is based on reviews of the previous research about women and pesantren. Thi study shows that there are three types of nyais role in managing pesantren education. First, a nyai who hold clear responsibility, work division and at the same time owned authority in managing a male and female students. Second, a nyai who has a clear division of work, and responsibility but does not have authority in managing a male and female students. And third, a nyai who leads a sepcific female pesantren and hold authority, responsibility and task in developing her pesantren. It is through various method of learning, espceially memorization of knowledge and the Qur'an, that tradition and knowledge of Islamic tradional subjects in pesantren are preserved and practiced.
\end{abstract}

Keywords: pesantren, education management, women, authority, knowledge

DOI: http:/ / dx.doi.org/10.20414/ujis.v21i1.1178

\section{Introduction}

ISLAMIC EDUCATION management as a scientific discipline in formal education system is considered a new discipline. In Indonesia, it emerged in 2007 and was broadly introduced as a new department in numbers of Islamic higher education institutions as the exchange of Islamic Education department which previously known as 'Kependidikan Islam'. The 
development of this discipline could not be separated from the emergence of the same trend in public universities in 2005, when the department of education administration in many universities was changed into the education management. The implication of this discussion is the urgency to find the philosophical basis for its scientific discipline.

In his paper, Irawan argues that Islamic education management is a science by showing that it has a formal and material object that involves science of management as its formal object and the practice of managing education institutions as its material object. ${ }^{1}$ Meanwhile, Abdul Munir Mulkhan ${ }^{2}$ states that the problem of Islamic education practices lies in the absence of Islamic theories and philosophy that is used in practice as well as discourses of Islamic education management. He points out that most of the Islamic education practices are based on western theories of management, borrowing other 'secular' theory to support the practices of Islamic education management. An analogous story for this case is like a bike race, the racer from Islamic education does not have bicycle himself. As an alternative, he believes that the concept of cognizance (makrifat quotient) can be used as an Islamic philosophy that shall be derived by managers in Islamic education management practices as he called it "prophetic manager".

In Indonesia, Islamic education has been practiced since the 18th century. Steenbrink argues that in 1819, the governor Van Der Capellen wrote a report that there were numbers of Islamic education in Java which use Arabic text. ${ }^{3}$ In line with what is reported in Steenbrink's work, Brumund as cited by Dhofier, ${ }^{4}$ wrote a book on the education system in Java in 1857 which was

\footnotetext{
${ }^{1}$ Irawan, "Paradigma Keilmuan Pendidikan Islam," Manageria Jurnal Manajemen Pendidikan Islam 1, no. 2 (2016): 297-315.

${ }^{2}$ Abdul Munir Mulkhan, "Manajer Pendidik Profetik dalam Konstruksi Kesalehan Makrifat," Manageria: Jurnal Manajemen Pendidikan Islam 1, no. 1 (May 2016): 1-21.

${ }^{3}$ Karel A. Steenbrink, Pesantren Madrasah Sekolah Pendidikan Islam dalam Kurun Modern (Jakarta: LP3ES, 1991), 2.

${ }^{4}$ See Zamakhsyari Dhofier, Tradisi Pesantren: Studi Pandangan Hidup Kyai dan Visinya Mengenai Masa Depan Indonesia (Jakarta: LP3ES, 2011).
} 
then followed by many other scholars who wrote about Islam, pesantren, as well as traditions in Java. Apart from the critic of J.A. van der Chijs that the education system of traditional Islamic teaching was inappropriate since it only emphasizes on reading and remembering Arabic text without really understand the meaning. ${ }^{5}$ The practice has proven that, historically, Islam in Indonesia has a tradition of an education system that has been practiced by generations. By learning to the best practices of Islamic education management of pesantren, we shall understand on how we may ground the management concept of Islamic education based on Indonesian Islam.

Pesantren management has become a focus of research by scholars. These include Pesantren Aji Mahasiswa Al-Muhsin Krapyak Wetan Yogyakarta, Pesantren Darul Hikmah Kutoarjo, Pesantren Al-Raisiyah Mataram, and Pesantren Annuriyah, just to name some. ${ }^{6}$ Other studies that specifically focus on women role and gender at pesantren have been also done Nabiel Laily, ${ }^{7}$ Nelly van Doorn-Harder, ${ }^{8}$ and Bianca J. Smith and Mark R. Woodward. ${ }^{9}$ Some of these work portrayed the practice of education management using theories of management such as George R. Terry which comprises of planning, organizing, actuating, and controlling (POAC). They also explore three aspects of management that include curriculum, human resources, and financial management of pesantren. However,

5Steenbrink, Pesantren Madrasah.

'Yusuf M. Hamdani, "Manajemen Pendidikan Pondok Pesantren Studi kasus Pada Pondok Pesantren Aji Mahasiswa Al-Muhsin di Krapyak Wetan Yogyakarta" (Thesis, Universitas Islam Negeri Sunan Kalijaga Yogyakarta, 2009); see also Iyus Herdiana Saputra, "Manajemen Pondok Pesantren Darul Himah Kutoarjo Jawa Tengah" (Thesis, Universitas Islam Negeri Sunan Kalijaga Yogyakarta, 2009); Nurul Yakin, "Pola Manajemen Pondok Pesantren Al-Raisiyah Mataram," Jurnal Penelitian Keislaman 9, no. 1 (2013): 75-92; Siti Rodliyah, "Manajemen Pondok Pesantren Berbasis Pendidikan Karakter (Studi Kasus di Pondok Pesantren 'Annuriyyah' Kaliwining Kecamatan Rambipuji Kabupaten Jember)," Cendekia: Kependidikan dan Kemasyarakatan 12, no. 2 (December 2014): 299-314.

${ }^{7}$ Nabiela Laily, Leadership and Gender Construction: Perspectives of Nyais in Pesantren Community in Indonesia (Saarbrudken: Lambert Academic Publishing, 2010).

${ }^{8}$ Nelly van Doorn-Harder, Women Shaping Islam: Indonesian Women Reading the Qur'an (Urbana: University of Illinois Press, 2006).

${ }^{9}$ Bianca J. Smith and Mark Woodward, eds., Gender and Power in Indonesian Islam: Leaders, Feminists, Sufis and Pesantren Selves (London; New York: Routledge, 2016). 
those works have not paid sufficient attention to the women's role in such aspects. This paper tries to fill this gap by examining the role of women leader (nyai) in pesantren education management. It critically examines previous works on these issues and maps the role of nyai in pesantren management. We argue that women play important role in running management of Islamic school.

Discussion about women in the Islamic tradition particularly pesantren institution is always interesting, as those who were recognized as one of the elements of pesantren is only a kyai (male leader of pesantren), ${ }^{10}$ while nyai (female leader or the wife or daughter of Kyai) has not been described specifically. Dhofier further states "some basic elements that must be available in any pesantren are pondok (dormitory), mosque, kitab kuning teaching, santri and the kyal". Steenbrink stated that "the wife of kyais never achieved significant role". ${ }^{11}$ In pesantren tradition, kyai is a charismatic religious leader who is honored because of his knowledge and deep religious understanding ('alim), whereas a nyai as kyai's wife also respected as the leader of female's boarding school and having good religious knowledge. However, some people still believe that women's leadership in a pesantren is mainly because of her husband position as a kyai, as if women would never achieve the position by themselves. ${ }^{12}$

In her book entitled Women for Traditional Islamic Education Institutions in Indonesia Negotiating Public Spaces, Srimulyaniargues that women (Nyais) in pesantren Seblak, Jombang, East Java, are important figures. ${ }^{13}$ They have played very significant roles not only in daily pesantren management, but also in society and political life. Srimulyani analyzes her finding using sociological and anthropological approaches to depicting the agency

${ }^{10}$ See Dhofier, Tradisi Pesantren, 93.

${ }^{11}$ Steenbrink, Pesantren Madrasah.

${ }^{12}$ Siti Chusniyah, "Nyai Dadah: Sosok Pemimpin Perempuan Di Pesantren (Studi Life History Pemimpin Pesantren Putri Huffadhul Quran Al Asror Di Kecamatan Gunungpati, Semarang)" (Undergraduate Thesis, Universitas Negeri Semarang, 2015).

${ }^{13}$ Read further Eka Srimulyani, Women from Traditional Islamic Educational Institutions in Indonesia Negotiating Public Spaces (IIAS, Amsterdam University Press, 2012). 
performed by nyais in pesantren. Another paper that seemed to be relevant is the work of Ambarwati and Husna who wrote gender responsive of pesantren management with the case in Pati, Central Java. Unfortunately, they only explained theoretical views on gender issues and failed to depict empirical cases of how this gender responsive management been practiced. ${ }^{14}$ This paper describes women's role in managing pesantren education from the managerial perspective by examining the division of work, responsibility and authority of nyai, as well as observing the knowledge on how it is preserved and managed in pesantren.

Pesantren as an educational institution consists of many elements that work together in supporting the aim of the institution. It could be understood using management theories. In traditional management theory, there are at least five elements that support the production process in an organization. Richard L. Daft calls it as $5 \mathrm{M}$ : Man refers to human resources; materials regarding the content in the business process; money as the financial sources to sustain the organization as well as all processes within the organization; method as a way of achieving the goals; and machine as the tool to foster visions' achievement. ${ }^{15}$ Not all those elements would be examined in this paper, yet it focuses on man issues as the critical element in leading the institution and method, particularly in managing the knowledge and tradition preservation.

\section{An Overview of Pesantren for Female Students}

Pesantren originally come from the word santri with the prefix pe and suffix an. It means place for santri. ${ }^{16}$ Dhofier argues that the term santri is believed to be derived from an Indian word sashtr meaning a person who understands holy books of Hindu religion, or a scholar mastering the holy books of Hinduism. Even though, the connection between pesantren and early Hindu-

\footnotetext{
${ }^{14}$ Ambarwati and Aida Husna, "Manajemen Pesantren Responsif Gender: Studi Analisis di Kepemimpinan Nyai Pesantren di Kabupaten Pati," Palastren Jurnal Studi Gender 7, no. 2 (December 2014): 445-456.

${ }^{15}$ See Richard L. Daft, Management, Ninth Edition. (South Western Cengage Learning, Vanderbilt University, 2010).

${ }^{16}$ Dhofier, Tradisi Pesantren.
} 
Buddhist influence is being questioned by current research that suggested a disconnection between present-day pesantren and the earlier Hindu-Buddhist tradition. In his book Kitab Kuning, Pesantren dan Tarekat, Van Bruinessen ${ }^{17}$ has argued that the concept of pesantren is a local Indonesian tradition. According to Dhofier, ${ }^{18}$ before the 1960 s, the centers of pesantren education in Indonesia were well known as pondok. He further assumes that the word pondok might be taken from Arabic word fundüq that means hotel or boarding school as pondok pesantren is a boarding school for santri or residences made from bamboo where santri live during their study. For the majority of people, pesantren is understood as a boarding school where santri learn about Islamic teachings and heritage through Arabic scripts known as kitab kuning (Arabic script written on "yellow paper").

Pesantren contribution in providing education for Indonesian people could not be ignored. Pesantren that is recognized as a typically Malay-Nusantara religious educational institution is growing rapidly throughout the country, especially in the rural north coast of Java. Based on 2008 data the number of pesantren in Indonesia reached 14,067 with 3,149,374 total students. Then, in 2014 the development of pesantren reached 27.290, increasing about 48.45 percent. The total number of students rose to 3,654,096. If in 2008 the number of pesantren that offer only kitab kuning studies is around 8,000, in 2014 the types of pesantren increased to 13.336 institutions. ${ }^{19}$ For centuries, before the state established formal schools for villagers, pesantren's role had been influential in serving Islamic education. 20

Since the 1910s, many Kyais have allowed the establishment of pesantren for female students. The first pesantren opened for female santri was Pesantren Denanyar, Jombang, established in 1917.21 Female santri were previously only given access to the

${ }^{17}$ Martin van Bruinessen, Kitab Kuning, Pesantren dan Tarekat, Yogyakarta: Gading Publishing (Yogyakarta: Gading Publishing, 2015).

18Dhofier, Tradisi Pesantren, 41.

${ }^{19}$ Syamsul Hadi et al., "Education Hybridization of Pesantren and Its Challenges in Rural Industrialization," Jurnal Pendidikan Islam 5, no. 2 (December 2016): 262.

20Steenbrink, Pesantren Madrasah.

${ }^{21}$ Dhofier, Tradisi Pesantren; see also Srimulyani, Women from Traditional. 
basic teachings in classical Islamic books in the forum of pengajian (Islamic preaching). Srimulyaninarrates that:

"Initially, in 1917 Kyai Bisri Syansury only set up a learning session in his pesantren for male pupils. In 1919, due to the efforts of Nyai Nurkhodijah who invited the local girls, the pesantren started to draw some neighborhood girls who came to the pesantren and learned informally at the rear terrace of Kiai Bisri's residence." 22

Today, female pesantren have developed not only in numbers but also in the specification of religious teachings. In 1978, according to Zamakhsari Dhofier's observation, the number of female santri reached $60 \%$ of the male santri. In Cukir, Jombang, for example, the number of female santri resided in the complex of pesantren Cukir and Seblak in 1978 was about 1100 persons. ${ }^{23}$ The increasing number of girls sent to study at pesantren showed the development of Muslim's awareness on the importance of the higher level of education for Muslim girls. Besides, the reason why parents sent their daughters to study at pesantren is that they want to preserve pesantren traditions as a consequence of sending their sons to public schools and universities in the hope for modern occupation for them in the future.

Within pesantren life, male and female dormitory are in a separated location. Besides location, most of the pesantren also conduct teaching and learning for male and female santri in different places although they stay in the same pesantren. Male and female relations are preserved under Islamic morality. They are obliged to cover their awrät. All activities that lead or open the chance for male and female to commit sexual intercourse outside marriage should be prevented as it is a violation and crime. Many pesantren preserve strict rule in the relation between male and female. The spatial segregation between men and women is strictly maintained in the majority of pesantren, although the Indonesian Muslim community in general does not emphasize this kind of segregation. ${ }^{24}$ Within a pesantren subculture, women are required to respect some specific norms and rules. What is commonly considered 'acceptable' for women

\footnotetext{
22Srimulyani, Women from Traditional, 74.

${ }^{23}$ Dhofier, Tradisi Pesantren, 92.

${ }^{24}$ Srimulyani, Women from Traditional, 17.
} 
outside pesantren might not be 'acceptable' for women in pesantren. For example, wearing trousers is forbidden for female santri while it is a common trend for young women in the town and cities.

Even then, many pesantren were established specifically for girls. For example, in Kajen, Pati, 8 out of 27 pesantren are female pesantren, such as Pesantren Masyitoh, Pesantren Manbaul Ulum Putri, Pesantren Roudhotul Ulum Putri, Pesantren Manbaul Huda Putri, and Pesantren Salafiyah Putri. Almost all those pesantren are led by kyai, and only two of them are managed by nyai. ${ }^{25}$

Pesantren education aims to improving morality, training the students to develop their effort to respect spirituality and humanity values, teaching for honest behavior and attitude as well as morality and preparing for pupils to live in modesty with a clean heart, not merely enriching students' thought with knowledge and explanation. ${ }^{26}$ Different from public education, Islamic education focuses on knowledge and skills that are useful for religious appreciation. ${ }^{27}$ Those aims are applicable both for male and female students as Islam regard both sexes as equal. The tradition of living in pesantren which is unique such as discipline in conducting five times prayers and other Muslims obligations is far more important than a sole formal teaching, the former brought about the religious impact in pupils live. Also, Steenbrink noted that not all parents and students hope to be an 'ulama' $\bar{a}$ ' by studying at pesantren, rather how to be a good Moslem. ${ }^{28}$

\section{Division of Work, Authority and Responsibility}

Following the 5 M-theory, man as the main factor for management activity will be discussed by examining the role of kyai and nyai in pesantren. The concept of work separation which contained the discourse of authority and responsibility in this paper is observed in management principles. In the principles of management, Henry Fayolargues that works should be divided

\footnotetext{
${ }^{25}$ Chusniyah, "Nyai Dadah."

26Dhofier, Tradisi Pesantren, 18.

${ }^{27}$ Steenbrink, Pesantren Madrasah, 24.

${ }^{28}$ Ibid., 17.
} 
among individuals and groups to ensure that effort and attention are focused on special portions of the task. ${ }^{29}$ Authority and responsibility should be defined, there should be a discipline, unity of command, unity of direction, centralization, and hierarchy, order, equity, and initiative to foster the organization to obtain a competitive advantage. The division of work, authority and responsibility principles are made to understand women's role in Islamic education management practices particularly those in pesantren education.

Srimulyani argues that pesantren institution is in fact more than just an educational institution or school as people commonly perceive, where the students come, get in and learn, yet it is also a specific sub-culture of the Indonesian Muslim community. ${ }^{30}$ A pesantren has its social hierarchy, culture, leadership structure, unique rules and principles that might differ from those in the surrounding community, and these include matters related to women's lives. Scholars describe a pesantren as a 'little kingdom' because of its relative autonomy to organize its community. ${ }^{31}$ The social hierarchies of pesantren in Java reveal the undeniable influence of the Javanese social structure, but modified by Islamic tradition. ${ }^{32}$ The kyai and his family establish a 'higher' or 'upper' class among their pesantren fellows, some of whom might also come from families with a relatively high socioeconomic status. In the case of the kyai and his family, this status is increased by religious power and authority, the statement also applies equally to learn an active nyai.

The status of Javanese women tends to be tied to that of their husbands, "since all individuals in Java must be ranked differentially about each other, husbands and wives are so ranked, and husbands enjoy higher status than their wives."33 In pesantren tradition, a kyai gains charisma and social respect due to his knowledge and religious understanding. Nyai as the wife of a

${ }^{29}$ See Daft, Management.

${ }^{30}$ Srimulyani, Women from Traditional, 16.

${ }^{31}$ Ibid.; see also Dhofier, Tradisi Pesantren, 94.

${ }^{32}$ Syarifatul Marwiyah, "Rekonfirmasi Identitas Nyai di Pesantren," Fenomena 15, no. 1 (April 2016), accessed June 19, 2017, http://ejournal.iainjember.ac.id/index.php/fenomena/artide/view/ 557.

${ }^{33} \mathrm{Keeler}$ in Srimulyani, Women from Traditional. 
kyai is also respected as a woman leader in pesantren, as well as a public figure. Unfortunately, some people still believe that the success of nyai in managing a pesantren was due to the influence of a kyai as her husband. Whether or not that this notion is true, the practices in some pesantren are varied.

Before discussing the variation in nyais' roles, their task, responsibility and experiences in managing pesantren, it is essential to understand about kyai and nyai themselves. It is commonly believed that pesantren is a symbol of the small kingdom where the kyai is the one who holds an absolute power and authority. None of the santri may challenge or oppose kyais power, because kyais have higher charisma and influence. Even though some of the kyai are living in rural areas, they enjoy respect from the community in its surrounding since they considered as part of an elite group in social, politics and economic structure of Indonesian people. Kyais main responsibility is teaching and preaching Islam. Some believe that they should also understand and take part in politics. With their superiority in Islamic knowledge, lay people believe that kyai understands more about God's greatness, so they stay in an unreachable position. The more a kyai owned a big number of santri, the higher status and influence he will gain. ${ }^{34}$ Kyai's intellectual and kinship network is upheld to sustain the existence of pesantren tradition.

Nyai literally means a married woman. Marcoes divided muballigah (women preachers) into two categories: ustadhah and nyai. ${ }^{35}$ In her description, nyai is the status a woman derives from her father or husband. When a woman marries a kyai, she will automatically become a nyai, regardless of her family background and education. In many aspects, a nyai is permeated with a particular 'power' and hence is legitimated to undertake certain tasks and duties because of her affiliation with a kyai's family. A nyai can also be seen as a 'mother' for all the students. In many cases, a nyai exercises 'unofficial power' which allows her to act on behalf of the pesantren leadership, especially in matters related to female students.

${ }^{34}$ Dhofier, Tradisi Pesantren, 94.

${ }^{35}$ Srimulyani, Women from Traditional. 
The roles experienced by nyai in managing pesantren education institutions are varied about each pesantren cultures. In term of management principles of authority, a division of work and responsibility, there are three types of managerial role carried out by nyai could be outlined in this paper.

Firstly, nyai hold a position as leader (pengasub) of pesantren that have both male and female pupils and she has the authority in determining pesantren policy regarding knowledge, and human resource management as well as determining male staff capability for leading communal prayer. This type of management is a rare case and could be achieved solely by a nyai who has a deep understanding of Islamic teachings, as well as leadership capability and charisma so that she could be regarded as equal as kyai. This first type is best depicted by the role of Nyai Khoiriyah from Pesantren Seblak.

In special cases of pesantren Seblak, Nyai Khoiriyah has influential roles both in pesantren leadership and the wider community. She holds an authority as pesantren leader as kyai usually does. As a nyai with deep knowledge and understanding of Islamic teachings, she experienced an authority in both pesantren management and 'Ulama' (the making of a religious leader). Srimulyani argues "the fact that Nyai Khoiriyah had remained in Mecca, the center of Islamic learning, for almost 20 years would significantly endorse the perception that she was equipped with the highest religious authority in the Islamic sciences." 36 Nyai Khoiriyah was also recorded as a director of the Pesantren Tebuireng for the transition period before Kyai Yusuf Hasyim was appointed in 1965. She was the leader of both male and female pesantren and managed male and female pesantren staff as well. Further, Nyai Khoiriyah tested some male teachers on their fluency in reciting the Qur'an to determine if they were eligible to be the imam of the communal prayers. ${ }^{37}$ The roles show that a nyai could have an authority equal to a kyai when she has the capability, knowledge and understanding of many branches of Islamic teaching.

36Ibid., 33.

${ }^{37}$ Ibid., 91. 
Secondly, responsibility and work are divided between kyai and nyai. Nyai could perform as a leader for male and female pesantren, she is responsible for both pesantren, but the authority still held by kyai. This type of managerial role is performed by Nyai Rosyidah from pesantren Darus Sholah. According to Syarifatul Marwiyah, ${ }^{38}$ Nyai Rosyidah from Pesantren Darus Sholah, Kaliwates Jember, was appointed as a leader of pesantren Darus Sholah after her husband KH. Yusuf Muhammad, died due to an aircraft accident. She inherited leadership position because the kyai's sons are still young, and they were the adopted children. Since then, Nyai Rosyidah undertook the leadership of the pesantren. However, the leadership was still designated to KH. Nadzir Muhammad, the brother of $\mathrm{KH}$. Yusuf Muhammad. In daily business, Pesantren Darus Sholah is managed by Nyai Rosyidah, however the decision and policy making process is yet at the hand of KH. Nadzir Muhammad. ${ }^{39}$ This case shows a clear division of work between nyai and kyai in managing pesantren institutions, where Nyai Rosyidah lead and managed both male and female pupils pesantren, but the authority is upheld on the hand of the kyai. Marwiyah argues that:

"Historically, Nyai Rosyidah is the successor of Kyai (Gus Yus) in the matter of pesantren Darus Sholah leadership, as the leader of both male and female Pondok here, the management of the pesantren always reported any matter happened in the pesantren to Nyai Rosyidah. As a caretaker, she is responsible for all problems occurred in the pesantren. Even the management of male pesantren also communicate the problems to Nyai, she also undertakes the problems happened in male Pondok. However, for the important agendas she should report it to Kyai Nadzir. He is barely step in male Pondok as he also has his santri a bit far from Darus Sholah." 40

From management principles, the case in Pesantren Darus Sholah shows how responsibility and work are divided among human resources which lead the pesantren, while the authority lies on the hand of the foundations' leader to ensure unity of command and direction of various educational institutions under the same foundation. On the other side, nyai played a

\footnotetext{
${ }^{38}$ Marwiyah, "Rekonfirmasi Identitas."

${ }^{39}$ Ibid., 128.

${ }^{40}$ Ibid., 129.
} 
significant role in managing pesantren education institution. She performed as a leader for both male and female pesantren, a headmaster for primary school plus in the pesantren compound. She also managed all the matters regarding pesantren activities and resources such as financial, teachers performances and control education system in the pesantren as well as agendas of the pesantren.

Thirdly, authority and responsibility lie in the hands of nyai automatically when she managed a pesantren for female only. But, this happens when she match the requirements of having good knowledge and understanding of Islamic teachings, and particularly when the nyai memorizes the whole passages of the Qur'an. This type of managerial activity is performed by nyai Dadah at the Pesantren Putri Huffadhul Qur'an Al-Asror Gunung Pati Semarang. Nyai Dadah is a daughter of Kyai Zubaidi and Nyai Siti Markonah. She spent her teenage studying at Pesantren Al-Badriyah Demak, and she was a hafidzhoh (the one who memorizes the whole passages of Al-Qur'an). After Kyai Zubaidi had passed away, she continued to be the leader of Pesantren Putri Huffadzul Qur'an. In term of management, Nyai Dadah is the top leader and at the same time the authority of the pesantren. She is not only leading and managing but also teaching and becoming a 'mother' for all her students. ${ }^{41}$ The case is rather different from the previous cases. One reason is that Pesantren Huffadzul Qur'an Al Asror is a pesantren specific for female students who enroll in the institution to memorize Al-Qur'an. In this typical case, nyai is specifically responsible for female santri.

Also, in Pesantren Al-Munawir Krapyak Yogyakarta, some Nyai were also evidenced to play significant roles in putting the meaning in the pesantren processes. Nyai involved in pesantren policy making processes. That role was influenced by the process and experience within herself, her learning and skills as well as her perception and social structure of the pesantren that

${ }^{41}$ Chusniyah, "Nyai Dadah." 
interact each other to support nyais role. ${ }^{42}$ This argumentation supported the idea that nyais would gain access in policy and decision making when she has deep knowledge and religious understanding either in Islamic teaching branches or in memorizing the Qur'an. While Nyai who do not have such skills, knowledge, and experience are likely to take a role in domestic matters of the pesantren.

In fact, the leadership which is meant 'authority' of a pesantren will always end up in the hands of the kyai's immediate family, whether consanguineal or affinal. The term of a leadership period is not limited, usually the successor will remain in this position until his/her death. In official records, the Kyai's name always appears as a leader, even though in everyday reality, particularly in pesantren for female, there is a responsibility distribution and division of work among his wife, daughter, mother, or even sister. Eka Srimulyani notes:

"When I visited Pesantren Al-Fatimiyah, the biggest sub-pesantren in the well-known Pesantren Tambak Beras of Jombang in 2003, its leader was Kiai Nasir Abd. Fattah, although his wife was also actively involved in the teaching and leadership. Her mother, Nyai Musyarrofah, was Nyai sepub (senior Nyai) and was consulted in all the pesantren-related matters. Her position resembling that of the chair of the pesantren advisory board at that time, Nyai Musyarrofah still led the communal prayers of the pesantren female students in the small mosque in the compound of the pesantren for female. In Pesantren Lirboyo, both daughters of Kyai Anwar were active in managing the two pesantren for the female in the compound. In the traditional pesantren of Pacul Gowang, Kiai Aziz Mansur was assisted by both his wife and his sister, Nyai Farida, who was well-grounded in Qur'anic studies and had memorized whole passages of the Quran." 43

As an organizational unit, the leader in a pesantren manages not only academic matters, but also financial, human resources, curriculum, as well as the development of the organization. Practically, pesantren adopted a clear authority either in the hands of kyai, nyai or foundations leader. A clear task and responsibility division, that nyai mostly responsible for female pesantren, is

${ }^{42}$ Fahmi Muhammad Ahmadi, "Ibu Nyai dan Perubahan Sosial Pesantren: Perempuan dalam Struktur Sosial Pesantren Al-Munawir Krapyak Yogyakarta" (Dissertation, Universitas Indonesia, n.d.).

${ }^{43}$ Srimulyani, Women from Traditional, 45. 
either as imam (leader for communal prayer), as a teacher, or as a mother for the santris. The clear work division and responsibility is then followed by unity of command, discipline, the unity of direction, equity and initiative to ensure that the organization run well and experience continuous improvement.

\section{Tradition Preservation and Islamic Knowledge Management}

Pesantren is known as relying on the principle of "almuhafadzoh 'alal qodimil ashlah, wal abdzu min jadidin nafi that roughly means preserving the best from the previous generations, and taking what is beneficial from the new generations. In pesantren context, kyais always tries to maintain the basic purposes of pesantren education, i.e. preserving, preaching, and strengthening Islamic teaching and civilization. ${ }^{44}$ In maintaining pesantren traditions, kyai usually builds strong solidarity and cooperations among pesantren in the surrounding and Java in general. There are three ways performed by kyais to maintain leadership vision of their pesantren. They are: develop a tradition that the closest family member shall become the strongest candidate for pesantren leadership; develop endogamous marital alliances between kyais family; and improve knowledge transmission and intellectual transmission chain between kyais and their family. ${ }^{45}$

On the other hand, regarding taking the new advantageous matter from the new system, pesantren develop its teaching and management into new education systems such as madrasah and schools model. While today, the type of pesantren is mostly mixed between traditional teaching and a modern schooling system that adopt educational curriculum either from the department of education, the department of Islamic education from the Ministry of Religious Affairs, or develop its curriculum, besides continue teaching kitab kuning.

In classical pesantren tradition, knowledge is delivered using some methods ranging from a focus on individual student development known as sorogan, where students could individually

${ }^{44}$ Dhofier, Tradisi Pesantren, 72.

45Ibid., 101. 
come to the kyai and offer his understanding on a kitab kuning. Focused on a group of santri called bandongan or wetonan, where teachers read, translate, explained or interpret Islamic books in Arabic. The most commonly used are memorizing the passages or teaching materials.

Regarding how knowledge is managed in pesantren tradition, the definition of knowledge management is good to be understood in this context. Amrit Tiwana, quoting Tobing, defines knowledge management as "bringing off organizational knowledge to create business value to result in sustainable competitive advantage by optimizing the process of creation, communication, and application of all knowledge needed to obtain the aim of the organization." 46 Within the process, knowledge is shared and preserved so that the organization could optimize it in a competitive sense. In the context of pesantren, even though it is a modern type of pesantren that mixed between religious and secular knowledge, yet the religious portion outweighs that of the secular one. Many critics of pesantren learning method are in memorizing as mostly used in religious teachings.

Memorizing should not only be understood as a way of learning something, but also depict the mission of an institution, on how knowledge is managed. In pesantren, memorizing is commonly used for all religious subjects. For example in the subject Qur'an, santri should memorize some passages or verses in the Qur'an. They also have to memorize hadith, ulama's fatwa, figh principles, as well as theologist views. Also, santri should also memorize Arabic grammatical principles, Arabic literature (balagah), Arabic words of wisdom (mahfüāat) and the like. Even for secular subjects that should be learned analytically, also affected by this way of learnings, many students memorize the materials in science like mathematics or physics. Students were not encouraged to discuss or compare the materials that need deeper understanding. Memorizing becomes a unique and typical method of learning in most of the pesantren institutions.

${ }^{46}$ Paul L. Tobing, Kowledge Management Konsep, Arsitektur dan Implementasi, Yogyakarta: Graha Ilmu (Yogyakarta: Graha Ilmu, 2007), 23. 
Memorizing is the way of collecting the information and accumulating knowledge. As a consequence, santri tend to master religious knowledge in an encyclopedic way rather than analytical one. Memorizing is aimed at mastering basic concepts that would be used in the analysis, and not intended to understand something ${ }^{47}$. For those who get used to the academic and analytical way of thinking would likely question this method. It does make a sense when J.A. van der Chijs stated about indigenous education that refers to pesantren tradition of memorizing Arabic texts without really understand the meaning, "even though I do agree if indigenous schools need to be interspersed by indigenous tradition, but I could not admit it since that habit is too bad, so that could not be used in indigenous schools." (my translation is taken from Steenbrink).48 Memorizing does not create a new idea, it only reproduces old thoughts.

Knowledge, in pesantren tradition is managed by memorization method. Furthermore, memorizing Islamic teachings would not only preserve knowledge that has been written in Kitab Kuning, but also will maintain the unwritten Islamic tradition that has been diffused orally by generations. By considering the purpose of pesantren institutions stated by Zamakhsyari Dhofier, ${ }^{49}$ it is understood that pesantren is not aimed at creating new knowledge. On the other hand, pesantren manages the knowledge in such a way that it could be preserved, and how Islamic knowledge that has been accumulated during periods of generations could be sustained and practiced continuously. ${ }^{50}$

In the context of managing and spreading knowledge, nyai also plays a significant role. For example Nyai Rosyidah at pesantren Darus Sholah, besides becoming the leader in religious

${ }^{47}$ See Hendro Prasetyo, "Pesantren, FU, dan FISIP UIN Jakarta Belajar Isam dari tiga Kecamatan," in Dari Pesantren Untuk Dunia: Kisah-Kisab Inspiratif Kaum Santri, ed. Komaruddin Hidayat (Jakarta: Prenada Media Group in collaboration with PPIM UIN Jakarta, 2016), 135.

48 Steenbrink, Pesantren Madrasah, 3.

${ }^{49}$ Dhofier, Tradisi Pesantren, 72.

${ }^{50}$ See Prasetyo, "Pesantren, FU, dan FISIP UIN Jakarta Belajar Isam dari tiga Kecamatan," 135. 
matters such as the leader of communal prayers for female santri, she also delivers tausiyah (advice for a group of santri), teaching the Qur'an and Kitab Kuning. ${ }^{51}$ The same cases for Nyai Dadah as the leader and authority of Pesantren Putri Huffadzul Qur'an Al-Asror. Karel A. Steenbrink ${ }^{52}$ also confirmed the role of nyai in knowledge sharing and knowledge transmission of traditional pesantren. He argues that commonly, religious teaching was performed by kyai or male teachers, however, there are some of the female teachers (nyai) also conducted religious teaching for female, sometimes they also teach young male santri.

Regarding intellectual capacity, nyai's role could not be ignored or underestimated. Today, many nyais (Kyai's daughters) enjoyed high academic achievement and experienced good formal education both in home country universities as well as overseas. Learning from historical narration as best depicted by Srimulyani 53, Kyai Yusuf Hasyim, the director of Pesantren Tebuireng, recognized Nyai Khoiriyah's (leader of pesantren Seblak) intellectual capacity in the Islamic sciences. He attributed the title 'Kiai putr' (female Kyai) to Nyai Khoiriyah. Another leader of the local pesantren in the area confirmed Nyai Khoiriyah's capability.

"One of her students who used to accompany her in her activities also said that Nyai Khoiriyah was brave enough to express her opinion even if it opposed those of the men in a babsul masail attended by the wellknown Kyai or ulama: "Who dares to oppose the opinions of the Kyai sepuh [senior kiai] in babsul masail? But Nyai Khoiriyah was brave enough to do that. She referred to the classical Kitab Kuning to support her opinion, having equal mastery of the Kitab Kuning as that Kyai did." 20 Ulama in Islam also has a religious authority for generating fatwa. For the NU community, the fatwa is a product of a babsul masail or meeting of learned religious leaders/ulama. As mentioned above, Nyai Khoiriyah was one of the participants in the bahsul masail among ulama/ Kyai in Jombang." ${ }^{54}$

Both nyai and kyai play an important role in preserving tradition and manage knowledge in pesantren institutions, and

\footnotetext{
51Marwiyah, "Rekonfirmasi Identitas," 130.

52Steenbrink, Pesantren Madrasah, 12.

${ }^{53}$ Srimulyani, Women from Traditional.

54Ibid., 91.
} 
most of them are successfully bring the institutions to exist in competition with other educational institutions in Indonesia. Although many factors influence the development of pesantren, managerial elements could not be taken lightly. This conclusion is supported by Marhumah ${ }^{55}$ in her research about how knowledge about gender is socialized by kyai and nyai in Pesantren Al-Munawir and pesantren Ali Maksum Krapyak Yogyakarta. She found that both kyai and nyai play an important role in one of the knowledge management processes, socialization. However, Kyai has a stronger role than nyai due to the greater chance he owned to interact with santri as a teacher. Their role was categorized into three, namely maximalist, moderate and minimalist role.

\section{Conclusion}

Islamic education management is considered as a new discipline particularly in Islamic education institutions. The problem is not only on a philosophical basis, but also most of the theories applied in managing Islamic education were adopted from western theories. In fact, the practice of Islamic education management has been performed for centuries in the form of pesantren institutions which is then developed into madrasah and school form. In searching for a theoretical basis for Islamic education management, we can examine its practices from pesantren institutions whose organization was managed by kyai and nyai.

When a woman becomes a nyai, either by inheritance or by marriage, the status comes with duties and expectations from both the pesantren and the community. If a nyai is capable of and willing to work hard, she can fill an important position in the pesantren and community leadership. A nyai who is competent in Islamic studies or Qur'anic passages memorization will be an instructor for female students. Some also hold the role of instructor or speaker in certain forums. Some nyai also has the

${ }^{55}$ See further Marhumah, "Gender dalam Lingkungan Sosial Pesantren Studi tentang Peran Kiai dan Nyai dalam Sosialisasi Gender di Pesantren Al-Munawir dan Pesantren Ali-Maksum Krapyak" (Dissertation, Universitas Islam Negeri Sunan Kalijaga Yogyakarta, 2008). 
chance to manage or lead the women in a pesantren or, in a rare case, a nyai can even become the leader of both men and women in the pesantren. When a kyai dies, a nyai can replace him, although commonly nyai will restrict their activities to pesantren for female or might reach both male and female pesantren management but restricted in task and responsibility not in authority. If the leadership role is taken over by her son, a nyai will become a respected 'person to be consulted' and will have symbolic authority as a nyai sepuh (senior nyai).

Regarding division of work, authority and responsibility, there is three types of nyai (women) role in managing pesantren education. First, a nyai who hold clear responsibility, work division and at the same time owned authority in managing pesantren which have male and female santri. This case was best described by the role of Nyai Khoiriyah at Pesantren Seblak. Second, a Nyai who has a clear division of work, and responsibility, but does not have authority in managing pesantren which have male and female santri, the case of Nyai Rosyidah at Pesantren Darus Sholah. And third, for a nyai who lead a female specific pesantren she will automatically hold the authority, responsibility and task in developing her pesantren, the case of Nyai Dadah.

In terms of knowledge management, the pesantren tradition is preserved by the system of leadership as well as the system of knowledge delivery, sharing, and preservation. The method of memorization, the most popular method of learning in pesantren, is particularly suitable with the main aim of pesantren. Furthermore, memorizing Islamic teachings would not only preserve knowledge that has been written in kitab kuning, but also will maintain the unwritten Islamic tradition, that has been diffused orally by generations. By considering the purpose of pesantren institutions it is understood that pesantren is not aimed at creating new knowledge. On the other hand, it manages the knowledge in such a way that it could be preserved, and how Islamic knowledge that has been accumulated during periods of generations could be sustained and practiced continuously. 


\section{References}

Ahmadi, Fahmi Muhammad. "Ibu Nyai dan Perubahan Sosial Pesantren: Perempuan dalam Struktur Sosial Pesantren AlMunawir Krapyak Yogyakarta." Dissertation, Universitas Indonesia, n.d.

Ambarwati, and Aida Husna. "Manajemen Pesantren Responsif Gender: Studi Analisis di Kepemimpinan Nyai Pesantren di

Kabupaten Pati." Palastren Jurnal Studi Gender 7, no. 2 (December 2014): 445-456.

van Bruinessen, Martin. Kitab Kuning, Pesantren dan Tarekat, Yogyakarta: Gading Publishing. Yogyakarta: Gading Publishing, 2015.

Chusniyah, Siti. "Nyai Dadah: Sosok Pemimpin Perempuan Di Pesantren (Studi Life History Pemimpin Pesantren Putri Huffadhul Quran Al Asror Di Kecamatan Gunungpati, Semarang)." Undergraduate Thesis, Universitas Negeri Semarang, 2015.

Daft, Richard L. Management. Ninth Edition. South Western Cengage Learning, Vanderbilt University, 2010.

Dhofier, Zamakhsyari. Tradisi Pesantren: Studi Pandangan Hidup Kyai dan Visinya Mengenai Masa Depan Indonesia. Jakarta: LP3ES, 2011.

van Doorn-Harder, Nelly. Women Shaping Islam: Indonesian Women Reading the Qur'an. Urbana: University of Illinois Press, 2006. Hadi, Syamsul, Soetarto, Endriatmo, Sunito Satyawan, and Nurmala K. Pandjaitan. "Education Hybridization of Pesantren and Its Challenges in Rural Industrialization." Jurnal Pendidikan Islam 5, no. 2 (December 2016): 261-285.

Hamdani, Yusuf M. "Manajemen Pendidikan Pondok Pesantren Studi kasus Pada Pondok Pesantren Aji Mahasiswa AlMuhsin di Krapyak Wetan Yogyakarta.” Thesis, Universitas Islam Negeri Sunan Kalijaga Yogyakarta, 2009.

Irawan. "Paradigma Keilmuan Pendidikan Islam." Manageria Jurnal Manajemen Pendidikan Islam 1, no. 2 (2016): 297-315.

Laily, Nabiela. Leadership and Gender Construction: Perspectives of Nyais in Pesantren Community in Indonesia. Saarbrucken: Lambert Academic Publishing, 2010. 
Marhumah. "Gender dalam Lingkungan Sosial Pesantren Studi tentang Peran Kiai dan Nyai dalam Sosialisasi Gender di Pesantren Al-Munawir dan Pesantren Ali-Maksum Krapyak." Dissertation, Universitas Islam Negeri Sunan Kalijaga Yogyakarta, 2008.

Marwiyah, Syarifatul. "Rekonfirmasi Identitas Nyai di Pesantren." Fenomena 15, no. 1 (April 2016). Accessed June 19, 2017. http://ejournal.iainjember.ac.id/index.php/fenomena/article/view/557.

Mulkhan, Abdul Munir. "Manajer Pendidik Profetik dalam Konstruksi Kesalehan Makrifat." Manageria: Jurnal Manajemen Pendidikan Islam 1, no. 1 (May 2016): 1-21.

Prasetyo, Hendro. "Pesantren, FU, dan FISIP UIN Jakarta Belajar Isam dari tiga Kecamatan." In Dari Pesantren Untuk. Dunia: Kisah-Kisah Inspiratif Kaum Santri, edited by Komaruddin Hidayat. Jakarta: Prenada Media Group in collaboration with PPIM UIN Jakarta, 2016.

Rodliyah, Siti. "Manajemen Pondok Pesantren Berbasis Pendidikan Karakter (Studi Kasus di Pondok Pesantren 'Annuriyyah' Kaliwining Kecamatan Rambipuji Kabupaten Jember)." Cendekia: Kependidikan dan Kemasyarakatan 12, no. 2 (December 2014): 299-314.

Saputra, Iyus Herdiana. "Manajemen Pondok Pesantren Darul Himah Kutoarjo Jawa Tengah.” Thesis, Universitas Islam Negeri Sunan Kalijaga Yogyakarta, 2009.

Smith, Bianca J., and Mark Woodward, eds. Gender and Power in Indonesian Islam: Leaders, Feminists, Sufis and Pesantren Selves. London; New York: Routledge, 2016.

Srimulyani, Eka. Women from Traditional Islamic Educational Institutions in Indonesia Negotiating Public Spaces. IIAS, Amsterdam University Press, 2012.

Steenbrink, Karel A. Pesantren Madrasah Sekolah Pendidikan Islam dalam Kurun Modern. Jakarta: LP3ES, 1991.

Tobing, Paul L. Kowledge Management Konsep, Arsitektur dan Implementasi, Yogyakarta: Graha Ilmu. Yogyakarta: Graha Ilmu, 2007.

Yakin, Nurul. "Pola Manajemen Pondok Pesantren Al-Raisiyah Mataram." Jurnal Penelitian Keislaman 9, no. 1 (2013): 75-92. 